\title{
ВПЛИВ ПРОТЕЇНОВОГО ЖИВЛЕННЯ БУГАЙЦІВ НА НАКОПИЧЕННЯ ВАЖКИХ МЕТАЛІВ У М'ЯЗОВІЙ ТКАНИНІ І ПЕЧІНЦІ
}

\author{
Ящук Інна Василівна \\ аспірантка \\ Поліський національний університет \\ ORCID: 0000-0003-2515-4260 \\ E-mail: inna.yashchuk.9224@gmail.com \\ Савчук Іван Миколайович \\ доктор сільськогосподарських наук, Снс \\ Інститут сільського господарства Полісся НААН \\ ORCID: 0000-0002-2182-8857 \\ E-mail: isavchuk.zt@ukr.net
}

\begin{abstract}
Стаття присвячена дослідженню впливу протеїнового живлення бугайців за їх утримання в III зоні радіоактивного забруднення на екологічну якість продукції - найдовшого м'язу спини і печінки. Сфоормовано 2 групи молодняку великої рогатої худоби: I група (контрольна) - у складі основного раціону згодовували зерносуміш № 1 з люпином вузьколистим місцевого виробництва; II група (дослідна) - отримувала зерносуміш №2 з «умовно чистими» кормовими бобами. Підготовку зразків рослинного та тваринного походження для встановлення у їх складі важких металів здійснювали методом сухої мінералізації, аналіз - на атомно-абсорбційному спектрометрі «Квант - 2А». Коефіцієнти переходу (КП) важких металів у ланцюгу „раціон - продукція (м'язова тканина і печінка)” визначали за формулою: КП = Ввмп/Ввмр. х 100, де КП коефріціснт переходу; Ввмп - вміст важких металів у продукції тварин, ме/ке; Ввмр - вміст важких металів у добовому раціоні, ме. Використання для відгодівлі бугайців у зоні радіоактивного забруднення зерносуміші №2 (пшениия + овес + кормові боби) замість аналогічної кількості за масою зерносуміші №1 (пшениия + овес + люпин), позитивно позначилося на екологічній якості яловичини, знижуючи в найдовшому м'язі спини концентрацію важких металів. Акумуляція важких металів у найдовшому м'язі спини і печінці піддослідних бугайців була значно нижчою за гранично допустиму концентрацію. Заміна в складі зерносуміші 30\% (за масою) люпину на відповідну кількість кормових бобів для молодняку великої рогатої худоби за його відгодівлі у III зоні радіоактивного забруднення сприяе значно меншому нагромадженню і переходу важких металів у м'язову тканину тварин: $\mathrm{Pb}$ - на 49,7\% і 0,30\% абс., Cd - 25,0 і 0,32, Cu - 8,3 і 0,35 ma Zn - на 1,1\% i 0,12\% абс. відповідно.
\end{abstract}

Ключові слова: бугайці, найдовший м'яз спини, печінка, люпин вузьколистий, кормові боби, концентрація, важкі метали.

DOI: https://doi.org/10.32845/bsnau.lvst.2021.4.31

Аналіз екологічної ситуації в Україні свідчить про те, що забруднення довкілля важкими металами за останні десятиліття збільшилося у кілька разів і за прогнозами продовжуватиме зростати [1-3]. Негативні екологічні зміни в агроекосистемах посилюються порушенням норм і правил застосування мінеральних добрив і пестицидів. Антропогенний вплив на агроекосистеми навколо промислових міст, у тому числі через інтенсифікацію ведення традиційного землеробства, на жаль, посилюється в різних країнах світу [4]. Велику небезпеку в сучасній екосистемі, як вказують М.J. Notten та iн., V. Brygadyrenko i V. Ivanyshyn, Z.L. Неa та ін. [57], становить забруднення ґрунтів такими елементами як Pb, $\mathrm{Cd}, \mathrm{Cu}, \mathrm{Zn}$.

Потрапляння важких металів у ґрунт може призвести до накопичення небажаних для сільськогосподарських угідь концентрацій, поставити під загрозу родючість, перехід таких полютантів як $\mathrm{Pb}$ і $\mathrm{Cd}$ з грунту в рослини, що йдуть на корм тваринам та можуть входити до раціону будь-якого типу годівлі, здатне ускладнити виробництво високоякісної тваринницької продукції, а значить і сировини для виробництва харчових продуктів $[8,9]$. Рослини здатні накопичувати важкі метали із грунту у великих кількостях [10].

Доведено, що вміст $\mathrm{Pb}$ і $\mathrm{Cd}$ у внутрішніх органах і м'язах тварин за використання кормів з індустріально розвинутих регіонів у декілька разів перевищував їх рівень, ніж у тварин з екологічно чистих зон. За даними літературних

джерел відомо, що корми є основним джерелом надходження до організму тварин важких металів і можуть сягати до $99 \%$ від їх загальної кількості $[11,12]$. Забруднення атмосфери, гідросфрери та літоссрери важкими металами призвело до міграції і накопичення їх у продуктах харчування [7].

Беручи до уваги широкий спектр біологічної і токсичної дії важких металів, яка спричиняє негативний вплив на внутрішні органи й системи тварин [13-16], заслуговує на увагу необхідність удосконалення системи ведення галузі тваринництва та годівлі тварин у зонах підвищеного техногенного навантаження сільськогосподарського виробництва.

У зоні Полісся України, і зокрема, в зоні радіоактивного забруднення, організація повноцінної годівлі має досить важливе значення, адже за дефіциту поживних речовин у раціонах сільськогосподарських тварин накопичення ксенобіотиків у молоці та м'ясі значно збільшується. Достатне протеїнове, вуглеводне та мінеральне живлення тварин послаблює токсичну дію шкідливих речовин, зменшує всмоктування ${ }^{137} \mathrm{Cs}$ і важких металів із шлунково-кишкового тракту та збільшує їх виведення із організму [17, 18]. Водночас забезпечення тварин необхідною кількістю повноцінного перетравного протеїну - одна з головних проблем тваринництва цієї зони [19].

Виходячи 3 вищенаведеного, надзвичайно актуальними $€$ наукові дослідження щодо вивчення вмісту важких металів ( $\mathrm{Pb}, \mathrm{Cd}, \mathrm{Cu}, \mathrm{Zn})$ у кормах за їх вирощування в III зоні 
радіоактивного забруднення, використання у раціонах годівлі бугайців на дорощуванні й відгодівлі дерті бобових культур - люпину вузьколистого і кормових бобів.

Мета досліджень - встановити накопичення $\mathrm{Pb}, \mathrm{Cd}$, Cu i Zn в найдовшому м'язі спини та печінці бугайців за оптимізації їх протеїнового живлення різними високобілковими кормами.

Матеріали та методи досліджень. Експериментальні дослідження на бугайцях української чорно-рябої молочної породи проводили на території фізіологічного двору
Інституту сільського господарства Полісся НААН в умовах прив'язного утримання тварин. Для проведення досліду сформовано 2 групи молодняку великої рогатої худоби за методом збалансованих груп згідно з методичними положеннями Ібатулліна І.І. і Жукорського О.М. [20]. Дослідження проведено в III зоні радіоактивного забруднення внаслідок аварії на ЧАЕС (с. Грозине Коростенського району Житомирської області за щільності радіоактивного забруднення території до 5 Кі/км²) за наступною схемою (табл. 1).

Таблиця 1

Схема проведення досліджень

\begin{tabular}{|c|c|c|c|}
\hline \multirow[b]{2}{*}{ Групи } & \multirow{2}{*}{$\begin{array}{l}\text { Кількість } \\
\text { тварин у } \\
\text { групі, гол. }\end{array}$} & \multicolumn{2}{|c|}{ Періоди досліду } \\
\hline & & порівняльний (49 діб) & дослідний (135 діб) \\
\hline $\begin{array}{c}\text { I - } \\
\text { контрольна }\end{array}$ & 7 & $\begin{array}{c}\text { ОР (основний господарський раціон) - силос } \\
\text { кукурудзяний, сіно злакове, сіль кухонна + } \\
\text { зерносуміш №1 }\end{array}$ & $\begin{array}{l}\text { ОР (основний господарський раціон) - силос } \\
\text { кукурудзяний, сіно злакове, сіль кухонна + } \\
\text { зерносуміш №1 }\end{array}$ \\
\hline II - дослідна & 7 & ОР + зерносуміш №1 & ОР + зерносуміш №2 \\
\hline
\end{tabular}

Згідно зі схемою досліду, бугайці I (контрольної) групи отримували господарський раціон, який складався із силосу кукурудзяного, сіна злакового, солі кухонної та зер-

носуміші №1. Тваринам II (дослідної) групи, окрім кормів основного раціону, згодовували зерносуміш №2 (табл. 2).

Склад зерносумішей при проведенні досліджень, \% за масою

\begin{tabular}{|l|c|c|}
\hline \multicolumn{1}{|c|}{ Концентровані корми } & Зерносуміш №1 & 3ерносуміш №2 \\
\hline Пшениця & 50 & 50 \\
\hline Овес & 20 & 20 \\
\hline Люпин вузьколистий (безалкалоїдний) & 30 & - \\
\hline Кормові боби & - & 30 \\
\hline Всього & 100 & 100 \\
\hline
\end{tabular}

До складу зерносуміші №1 для годівлі піддослідних тварин введені зернові концентрати власного виробництва, вирощені в III зоні радіоактивного забруднення внаслідок аварії на ЧАЕС (\% за масою): пшениця - 50, люпин - 30, овес - 20. Зерносуміш №2 складалася також із аналогічної кількості пшениці і вівса, а замість люпину вузьколистого використовували «умовно чисті» кормові боби, які вирощені на полях ДПДГ «Нова Перемога» Любарського району Житомирської області.

Годівля піддослідних тварин нормувалася відповідно до загальновизнаних рекомендацій [21, 22], склад раціону визначався методикою досліду. Утримання тварин обох піддослідних груп було аналогічним.

Підготовка зразків рослинного та тваринного походження для визначення важких металів здійснювалась методом сухої мінералізації згідно ГОСТ 26929 - 94, аналіз методом атомно-абсорбційної спектрофотометрії (спектрофотометр «Квант - 2А») згідно ГОСТ 30178-96.

Коефіцієнти переходу (КП) важких металів у лан- цюгу „раціон - продукція (м'язова тканина і печінка)” визначали за формулою: КП = Ввмп./Ввмр. х 100, де КП - коефіцієнт переходу; Ввмп - вміст важких металів у продукції тварин, мг/кг; Ввмр - вміст важких металів у добовому раціоні, мг. Даний коефіцієнт є відносним інтегрованим показником, котрий у \% відображає міграцію важких металів з раціону в продукцію, що дозволяє провести порівняльну оцінку переходу полютантів за різних типів годівлі бугайців.

Результати досліджень. Для вирішення проблеми забезпечення населення повноцінними і екологічно безпечними продуктами харчування необхідні дослідження, направлені на вивчення шляхів міграції важких металів (Кадмію, Плюмбуму, Купруму та Цинку) в ланцюгу корми $\rightarrow$ організм тварин $\rightarrow$ продукція (молоко та м'ясо), а також шляхів їх виведення з організму тварин.

У таблиці 3 наведені дані щодо вмісту важких металів у кормах, які використовувалися для годівлі піддослідних бугайців під час проведення експерименту.

Таблиця 3

Концентрація важких металів у кормах, мг/кг натурального корму

\begin{tabular}{|l|c|c|c|c|}
\hline \multirow{2}{*}{ Корми } & \multicolumn{4}{c|}{ Важкі метали } \\
\cline { 2 - 5 } & $\mathrm{Pb}$ & $\mathrm{Cd}$ & $\mathrm{Cu}$ & $\mathrm{Zn}$ \\
\hline Силос кукурудзяний & 1,686 & 0,038 & 2,94 & 12,0 \\
\hline Сіно злакове & 0,092 & 0,028 & 2,61 & 5,8 \\
\hline Зерносуміш №1 & 0,054 & 0,024 & 3,09 & 14,7 \\
\hline Зерносуміш №2 & 0,029 & 0,022 & 3,24 & 16,2 \\
\hline ГДК & 5,0 & 0,3 & 30,0 & 50,0 \\
\hline
\end{tabular}

Проведеними дослідженнями встановлено, що концентрація важких металів (Pb, Cd, Cu, Zn) у кормах, які були вирощені в III зоні радіоактивного забруднення внаслі- док аварії на ЧАЕС, не перевищувала нормативних вимог (ГДК). Наразі найбільша кількість $\mathrm{Pb}$ i Cd містилася у силосі кукурудзяному - 1,686 мг/кг (менше від ГДК на 66,3\%) і 0,038 
мг/кг (менше від ГДК на 87,3\%) відповідно. Наразі кількість Cu та Zn у кормах набагато нижча гранично допустимої концентрації - 2,61-3,24 та 5,8-16,2 мг/кг відповідно, що підтверджується даними вітчизняних авторів про дефіцит даних мікроелементів у кормах поліської зони України.

Уміст важких металів у м'ясі - один із важливих показників його якості в умовах антропогенного забруднення сільськогосподарських угідь і кормів токсичними елементами.

Визначення рівня $\mathrm{Pb}$ в продукції піддослідних тварин засвідчило, що його вміст у найдовшому м'язі спини та печінці був значно меншим за гранично допустиму концентрацію і варіював у межах 0,092-0,183 та 0,332-0,418 мг/кг відповідно (табл. 4). Водночас концентрація $\mathrm{Pb}$, який відноситься до кумулятивних ядів, у найдовшому м'язі спини бугайців II (дослідної) групи порівняно з показником I (контрольної) групи виявилася меншою на 0,091 мг/кг, або на 49,7\% $(\mathrm{P}<0,95)$. Дещо інша закономірність спостерігалася щодо накопиченням $\mathrm{Pb}$ у печінці піддослідного молодняку великої рогатої худоби. У цьому органі уміст Рb виявився більшим у тварин II групи відносно аналогів із I групи на 25,9\%.

Таблиця 4

Концентрація $\mathrm{Pb}$ у раціонах і продуктах забою бугайців

\begin{tabular}{|c|c|c|c|c|}
\hline \multirow{3}{*}{ Групи бугайців } & \multicolumn{4}{|c|}{ Концентрація Pb } \\
\hline & \multirow{2}{*}{ середньодобовий раціон, мг } & \multirow{2}{*}{ продукція, мг/кг } & \multicolumn{2}{|c|}{ \pm до контролю } \\
\hline & & & $\mathrm{Mг} / \mathrm{K \Gamma}$ & $\%$ \\
\hline \multicolumn{5}{|c|}{ Найдовший м'яз спини } \\
\hline I- контрольна & 30,63 & $0,183 \pm 0,018$ & - & - \\
\hline II - дослідна & 30,56 & $0,092 \pm 0,020^{*}$ & $-0,091$ & $-49,7$ \\
\hline ГДК & - & 0,50 & - & - \\
\hline \multicolumn{5}{|c|}{ Печінка } \\
\hline I - контрольна & 30,63 & $0,332 \pm 0,096$ & - & - \\
\hline II - дослідна & 30,56 & $0,418 \pm 0,053$ & $+0,086$ & $+25,9$ \\
\hline ГДК & - & 0,60 & - & - \\
\hline
\end{tabular}

Щодо переходу $\mathrm{Pb}$ із кормів раціону в найдовший м'яз спини молодняку великої рогатої худоби, то слід зауважити, що цей показник у тварин II (дослідної) групи виявився набагато нижчим, ніж у I (контрольній) групі (рис. 1). Так, коефіцієнт переходу $\mathrm{Pb}$ у м'язову тканину бугайців II групи становив 0,30\%, тоді як в контролі був вищим на 0,30\% абс. Використання у складі зерносуміші №2 кормових бобів зумовило інтенсивніше відкладення $\mathrm{Pb}$ в печінці тварин ІІ групи - 1,37\% порівняно з 1,08\% на контролі.

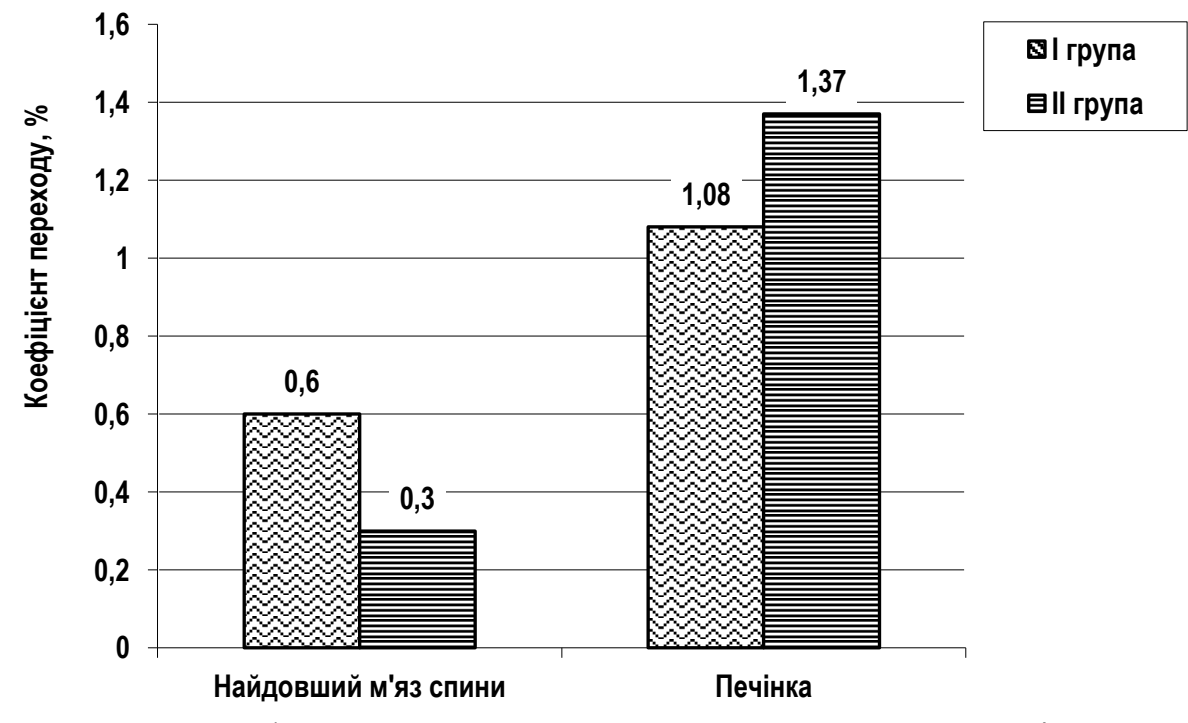

Кількість $\mathrm{Cd}$, що надходив до організму піддослідного молодняку великої рогатої худоби української чорнорябої молочної породи за його відгодівлі різними варіантами зерносумішей, був значно нижчим, ніж $\mathrm{Pb}$, що становило 0,832-0,837 мг/добу (табл. 5).

Рівень забруднення найдовшого м'язу спини бугайців $\mathrm{Cd}$ не перевищував гранично допустиму концентрацію. Так, цей показник у м'язовій тканині піддослідних тва-

рин I та II груп варіював у межах 0,018-0,024 мг/кг, що нижче за нормативні вимоги на 52,0-64,0\%. Слід наголосити, що концентрація $\mathrm{Cd}$ у найдовшому м'язі спини та печінці виявилася найнижчою у молодняку II (дослідної) групи, якому згодовували у складі зерносуміші 30\% (за масою) кормових бобів - 0,018 та 0,059 мг/кг відповідно. У тварин цієї групи вміст Cd в м'язовій тканині та печінці був нижчим на 25,0 та 4,8\% відповідно, ніж у аналогів із контрольної групи. 
Таблиця 5

Вміст Cd у раціонах і продуктах забою бугайців

\begin{tabular}{|c|c|c|c|c|}
\hline \multirow{3}{*}{ Групи бугайців } & \multicolumn{4}{|c|}{ Концентрація Cd } \\
\hline & \multirow{2}{*}{ середньодобовий раціон, мг } & \multirow{2}{*}{ продукція, мг/кг } & \multicolumn{2}{|c|}{ \pm до контролю } \\
\hline & & & $\mathrm{M \Gamma} / \mathrm{K \Gamma}$ & $\%$ \\
\hline \multicolumn{5}{|c|}{ Найдовший м'яз спини } \\
\hline I-контрольна & 0,837 & $0,024 \pm 0,005$ & - & - \\
\hline II - дослідна & 0,832 & $0,018 \pm 0,003$ & $-0,006$ & $-25,0$ \\
\hline ГДК & - & 0,05 & - & - \\
\hline \multicolumn{5}{|c|}{ Печінка } \\
\hline I- контрольна & 0,837 & $0,062 \pm 0,010$ & - & - \\
\hline II - дослідна & 0,832 & $0,059 \pm 0,006$ & $-0,003$ & $-4,8$ \\
\hline ГДК & - & 0,3 & - & - \\
\hline
\end{tabular}

Коефріцієнти переходу Cd в яловичину (найдовший $\mid$ відповідно (рис. 2).

м'яз) та печінку були невисокими - 2,16-2,87 та 7,09-7,41\%

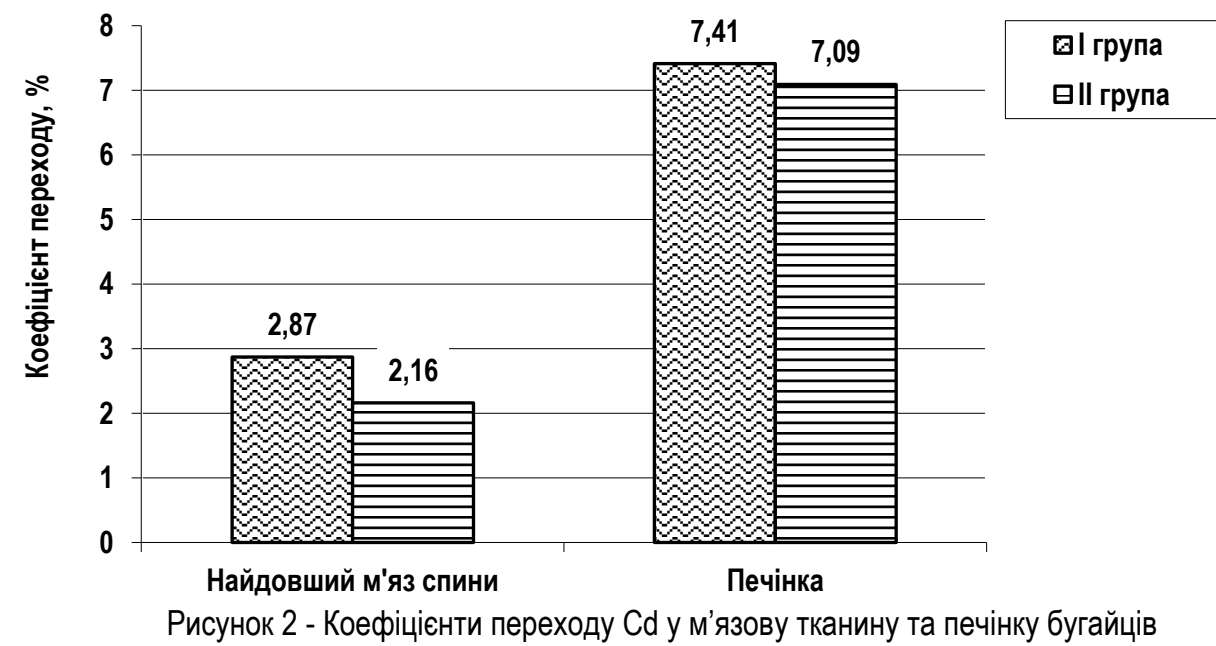

За введення до складу зерносуміші кормових бобів перехід $\mathrm{Cd}$ у найдовший м'яз спини тварин дослідної групи знижувався на $0,71 \%$ абс. порівняно 3 контролем. Найменшим коефіцієнтом переходу $\mathrm{Cd}$ у печінку відрізняється також молодняк II (дослідної) групи, а найбільшим - I (контрольної) групи.

Концентрація Сu у найдовшому м'язі спини молодняку BPX обох піддослідних груп була низькою (2,53-2,76 мг/кг) і не перевищувала ГДК (табл. 6). Використання для відгодівлі бугайців зерносумішей різного складу істотного впливу на вміст цього елемента у м'язах не мало. Основним

депо Сu в організмі тварин є печінка, вміст елемента у якій був вищим у 2,9-3,7 рази, ніж у найдовшому м'язі спини. За використання у складі запропонованих варіантів зерносумішей кормових бобів, концентрація $\mathrm{Cu}$ у печінці відносно контролю збільшувалася на 1,30 мг/кг, або на 16,3\% за невірогідної різниці. Водночас у молодняку ВРХ обох піддослідних груп уміст Сu в печінці був значно нижчим за нормативні вимоги (20,0 мг/кг).

Коефіцієнти переходу Сu із кормів раціонів у печінку бугайців були високими - 11,43-13,23\% порівняно з 3,62$3,97 \%$ - у найдовший м'яз спини.

Таблиця 6

Концентрація Сu у раціонах і продукції

\begin{tabular}{|c|c|c|c|c|c|}
\hline \multirow{3}{*}{ Групи бугайців } & \multicolumn{4}{|c|}{ Концентрація Сu } & \multirow{3}{*}{$\begin{array}{c}\text { Коесріцієнт переходу, } \\
\%\end{array}$} \\
\hline & \multirow{2}{*}{$\begin{array}{c}\text { середньо-добовий раціон, } \\
\text { мг }\end{array}$} & \multirow{2}{*}{ продукція, мг/кг } & \multicolumn{2}{|c|}{ \pm до контрольної групи } & \\
\hline & & & $\mathrm{Mr} / \mathrm{Kr}$ & $\%$ & \\
\hline \multicolumn{6}{|c|}{ Найдовший м'яз спини } \\
\hline I-контрольна & 69,53 & $2,76 \pm 0,56$ & - & - & 3,97 \\
\hline II - дослідна & 69,92 & $2,53 \pm 0,39$ & $-0,23$ & $-8,3$ & 3,62 \\
\hline ГДК & - & 5,0 & - & - & - \\
\hline \multicolumn{6}{|c|}{ Печінка } \\
\hline I - контрольна & 69,53 & $7,95 \pm 1,05$ & - & - & 11,43 \\
\hline II - дослідна & 69,92 & $9,25 \pm 0,78$ & $+1,30$ & $+16,3$ & 13,23 \\
\hline ГДК & - & 20,0 & - & - & - \\
\hline
\end{tabular}

Забруднення Zn найдовшого м'язу спини та печінки молодняку BPX обох піддослідних груп було невисоким i становило 9,2-9,3 та 54,9-58,1 мг/кг відповідно, що значно нижче за ГДК (табл. 7). Заміна у кормових раціонах тварин

30\% (за масою) дерті люпину на відповідну кількість дерті кормових бобів істотного впливу на концентрацію Zn в м'язовій тканині бугайців не мало. У печінці молодняку ВPX II (дослідної) групи уміст мікроелементу був дещо більшим, 
ніж у контролі (на 5,8\%) за невірогідної міжгрупової різниці.

Таблиця 7

Концентрація Zn у раціонах і продуктах забою бугайців

\begin{tabular}{|c|c|c|c|c|c|}
\hline \multirow{3}{*}{ Групи бугайців } & \multicolumn{4}{|c|}{ Концентрація Zn в: } & \multirow{3}{*}{$\begin{array}{c}\text { Коефіцієнт переходу, } \\
\%\end{array}$} \\
\hline & \multirow{2}{*}{$\begin{array}{c}\text { середньо-добовому } \\
\text { раціоні, мг }\end{array}$} & \multirow{2}{*}{ продукції, мг/кг } & \multicolumn{2}{|c|}{ 土 до контрольної групи } & \\
\hline & & & $\mathrm{Mr} / \mathrm{K} \Gamma$ & $\%$ & \\
\hline \multicolumn{6}{|c|}{ Найдовший м'яз спини } \\
\hline I - контрольна & 272,7 & $9,3 \pm 0,5$ & - & - & 3,41 \\
\hline II - дослідна & 276,6 & $9,2 \pm 0,3$ & $-0,1$ & $-1,1$ & 3,33 \\
\hline ГДК & - & 70,0 & - & - & - \\
\hline \multicolumn{6}{|c|}{ Печінка } \\
\hline I-контрольна & 272,7 & $54,9 \pm 4,0$ & - & - & 20,13 \\
\hline II - дослідна & 276,6 & $58,1 \pm 4,1$ & $+3,2$ & $+5,8$ & 21,01 \\
\hline ГДК & - & 100,0 & - & - & - \\
\hline
\end{tabular}

На основі проведених досліджень у III зоні радіоактивного забруднення виявлені певні закономірності трансформації важких металів у продукти забою бугайців. Так, за нашими даними, коефріцієнти переходу окремих металів становили (\%):

- у найдовший м'яз спини: $\mathrm{Cu}-3,62-3,97>\mathrm{Zn}-3,33$ $3,41>\mathrm{Cd}-2,16-2,87>\mathrm{Pb}-0,30-0,60$;

- у печінку: $\mathrm{Zn}-20,13-21,01>\mathrm{Cu}-11,43-13,23>\mathrm{Cd}$ $-7,09-7,41>\mathrm{Pb}-1,08-1,37$.

Це дає змогу стверджувати, що серед металівбіотиків найвищою міграційною і депонуючою активністю у найдовший м'яз спини відзначається $\mathrm{Cu}$, а в печінку - Zn. Щодо міграційної здатності досліджуваних металівтоксикантів, значними акумуляційними властивостями характеризується $\mathrm{Cd}$. Його коефіцієнти переходу в продукти забою бугайців були вищими в 3,6-9,6 рази порівняно з $\mathrm{Pb}$.

Висновки. Вміст важких металів у найдовшому м'язі спини і печінці піддослідних бугайців виявився значно нижчим за гранично допустиму концентрацію. Заміна в складі зерносуміші 30\% (за масою) люпину на відповідну кількість кормових бобів для молодняку великої рогатої худоби за його відгодівлі у III зоні радіоактивного забруднення сприяє значно меншому нагромадженню і переходу важких металів у м'язову тканину тварин: $\mathrm{Pb}$ - на 49,7\% і 0,30\% абс., Cd 25,0 і 0,32, Cu - 8,3 і 0,35 та Zn - на 1,1\% і 0,12\% абс. відповідно.

3 метою отримання екологічно безпечної яловичини в зоні техногенного навантаження, зниження накопичення у найдовшому м'язі спини важких металів доцільно використовувати в раціонах бугайців кормові зерносуміші такого складу (\% за масою): пшениця - 50, кормові боби - 30, овес 20.

\section{Список використаної літератури:}

1. Засєкін Д. Детоксикація надлишку важких металів в організмі тварин - запорука збереження здоров'я та одержання екологічно чистої тваринницької продукції. Науковий вісник НАУ. 2000. Вип. 28. С. 258-269.

2. Буцяк В.І., Кравців Р., Буцяк Г. Екологічний моніторинг ведення тваринництва у біохімічних провінціях. Львів: Папірус, 2005. 254 c.

3. Савчук І.М., Савченко Ю.І., Савченко М.Г. Виробництво тваринницької продукції в зоні техногенного навантаження. Житомир: Рута, 2014. 372 с.

4. Bigalke M., Ulrich A., Rehmus A., Keller A. Accumulation of cadmium and uranium in arable soils in Switzerland. Environmental Pollution. 2017. №221. P. 85-93. DOI: https://doi.org/10.1016/j.envpol.2016.11.035.

5. Notten M.J., Oosthoek A.J., Rozema J., Aerts R. Heavy metal concentrations in a soil-plant-snail food chain along a terrestrial soil pollution gradient. Environmental Pollution. 2005. №138 (1). P. 178-190. DOI: https://doi.org/10.1016/j.envpol.2005.01.011.

6. Brygadyrenko V., Ivanyshyn V. Chandes in the body mass of Megaphyllum kievense (Diplopoda, Julidae) and the granulometric composition of leaf litter subject to different concentrations of copper. Journal of Forest Sciense. 2015. Vol. 61(9). P. 369-376.

7. Hea Z.L., Yanga X.E., Stoffelab P.J. Trace elements in agroecosystems and impacts on the environment. Journal of Trace Elements in Medicine and Biology. 2005. №19. P. 125-140. DOI: https://doi.org/10.1016/j.jtemb.2005.02.010.

8. Маменко О.М., Портяник С.В. Вплив типів годівлі корів на вміст важких металів у молоці. Науковий вісник ЛНУВМБ імені С.3. Гжицького. Серія: Сільськогосподарські науки. 2019. Т.21. № 90. С. 38-48.

9. Сачко Р.Г., Лесик Я.В., Пилипець А.З., Грабовська О.С., Венгрин А.В. Вміст важких металів у грунті, кормах та біологічному матеріалі в агроекологічних умовах Лісостепу та Полісся. Науковий вісник ЛНУВМБ імені С.3. Гжицьког. 2013. Т.15. №3 (57). Частина 3. С. 415-420.

10. Hansen H.S., Knut Hove. Radiocaesium Ciovailabihty transfer of Chernobyl and tracer radiocatsium goest to milk. Health Prusics. 1991. Vol. 60. №5. P. 665-671.

11. Litwinczuk A, Drozd-Janczak A., Florek M. Zawartocs Metali ciezkich ( $\mathrm{Pb} \mid \mathrm{Cd}$ ) w mleku towarowym produkowanym w rejonach premyslowych I typowo rolniczych. Roczniki naukowe zootechniki. Annals of Animal Science. Institut zootechniki. 1999. T.26, Z. I. P. 219-228.

12. Hetmanska B., Tomasik P. The metal-metal interactions in biological systems. Water, air and Soil Pollut. 1994. Vol. 74. №3-4. P. 281-288.

13. Жукорський О.М., Семенов С.О.,Семенов Є.С. Вплив важких металів у раціонах на рівень їх накопичення в орга- 
нах і тканинах забійних свиней, продуктивність та екскрецію аміачного азоту. Вісник аграрної науки. 2018. №12 (789). С. 40 45.

14. Roggeman S., De Boeck G., De Cock H., Blust R., Bervoets L. Accumulation and detoxification of metals and arsenic in tissues of cattle (Bos Taurus), and the risks for human consumption. Science of The Total Environment. 2014. № 466-467 (1). P. 175-184. DOI: https://doi.org/10.1016/j.scitotenv.2013.07/007.

15. Hashemi S. Heavy metal concentrations in bovine tissues (muscle, liver and kidney) and their relationship with heavy metal contents in consumed feed. Ecotoxicokogy and Environmental Safety. 2018. №154 (15). P. 263-267. DOI: https://doi.org/10.1016/j.ecoenv.2018.02.058.

16. Peng L., Huang Y., Zhang J., Peng Y., Lin X., Wu K., Huo X. Cadmium exposure and the risk of breast cancer in Chaoshan population of southeast China. Environmental Science Pollution Research. 2015. Vol. 22 (24). P. 19870-19878. DOI: https://doi.org/10.1007/s11356-015-5212-1.

17. Савченко Ю.І., Савчук І.М. Трансформація нітратів, радіонуклідів, солей важких металів у м'ясо бугайців залежно від оптимізації вуглеводневого живлення. Вісник аграрної науки. 1998. № 3. С. 53-55.

18. Радіоекологічна оцінка раціонів при виробництві яловичини: [Монографія] за ред. Савченка Ю.І., Савчука І.М., Савченко М.Г., Карпюк Н.А. Житомир: ПП «Рута», 2017. 160 с.

19. Савченко Ю.І., Савчук І.М., Савченко М.Г. [та ін.]. Використання зернобобових на корм при виробництві молока і м'яса в зоні Полісся України: монографія; за ред. Савченка Ю.І., Савчука І.М. Житомир: Рута, 2014. 206 с.

20. Методологія та організація наукових досліджень у тваринництві: посібник; за ред. І.І. Ібатулліна,О.М. Жукорського. Київ: Аграрна наука, 2017. 328 с.

21. Теорія і практика нормованої годівлі великої рогатої худоби: монограффія; за ред. В.М. Кандиби, І.І. Ібатулліна, В.І. Костенка. Житомир: ПП «Рута», 2012. 860 с.

22. Ібатуллін І.І., Бащенко М.І., Жукорський О.М. та ін. Довідник з повноцінної годівлі сільськогосподарських тварин /за наук. ред. І.І. Ібатулліна і О.М. Жукорського. Київ: Аграрна наука, 2016. 336 с.

\section{References:}

1. Zasyekin, D., 2000. Detoksykatsiya nadlyshku vazhkykh metaliv v orhanizmi tvaryn - zaporuka zberezhennya zdorovya ta oderzhannya ekolohichno chystoyi tvarynnytskoyi produktsiyi [Detoxification of excess heavy metals in animals - the key to maintaining health and obtaining environmentally friendly livestock products]. Naukovyy visnyk NAU, issue 28, pp. 258-269.

2. Butsiak, V. I., Kravtsiv, R. and Butsiak, H., 2005. Ekolohichnyi monitorynh vedennia tvarynnytstva u biokhimichnykh provintsiiakh [Environmental monitoring of livestock farming in biochemical provinces]. Lviv: Papirus.

3. Savchuk, I. M., Savchenko, Y. I. and Savchenko, M. H., 2014. Vyrobnytstvo tvarynnytskoi produktsii v zoni tekhnohennoho navantazhennia [Production of livestock products in the area of man-made load]. Zhytomyr: Ruta.

4. Bigalke, M., Ulrich, A., Rehmus, A. and Keller, A., 2017. Accumulation of cadmium and uranium in arable soils in Switzerland. Environmental Pollution, №221, pp. 85-93. DOI: https://doi.org/10.1016/j.envpol.2016.11.035.

5. Notten, M. J., Oosthoek, A. J., Rozema, J. and Aerts, R., 2005. Heavy metal concentrations in a soil-plant-snail food chain along a terrestrial soil pollution gradient. Environmental Pollution, №138 (1), pp. 178-190. DOI: https://doi.org/10.1016/j.envpol.2005.01.011.

6. Brygadyrenko, V. and Ivanyshyn, V., 2015. Chandes in the body mass of Megaphyllum kievense (Diplopoda, Julidae) and the granulometric composition of leaf litter subject to different concentrations of copper. Journal of Forest Sciense, Vol. 61(9), pp. 369-376.

7. Hea, Z. L., Yanga, X. E. and Stoffelab, P. J., 2005. Trace elements in agroecosystems and impacts on the environment. Journal of Trace Elements in Medicine and Biology, №19, pp. 125-140. DOI: https://doi.org/10.1016/i.jtemb.2005.02.010.

8. Mamenko, O. M. and Portiannik, S. V., 2019. Vplyv typiv hodivli koriv na vmist vazhkykh metaliv u molotsi [Influence of feeding types of cows on the content of heavy metals in milk]. Scientific Messenger of LNU of Veterinary Medicine and Biotechnologies. Series: Agricultural sciences, № 90, pp. 38-48.

9. Sachko, R. G., Lesyk, Y. V., Pylypets, A. Z., Grabovska, O. C. and Venhryn, A. V., 2013. Vmist vazhkykh metaliv u hrunti, kormakh ta biolohichnomu materiali v ahroekolohichnykh umovakh Lisostepu ta Polissia [Content of heavy metals in soil, fodder and biological material in agroecological conditions of Forest-steppe and Polissya]. Scientific Messenger of LNU of Veterinary Medicine and Biotechnologies, №3 (57), pp. 415-420.

10. Hansen, H. S. and Knut, Hove, 1999. Radiocaesium Ciovailabihty transfer of Chernobyl and tracer radiocatsium goest to milk. Health Prusics, Vol. 60, №5, pp. 665-671.

11. Litwinczuk, A, Drozd-Janczak, A. and Florek, M., 1999. Zawartocs Metali ciezkich (Pb I Cd) w mleku towarowym produkowanym w rejonach premyslowych I typowo rolniczych. Roczniki naukowe zootechniki. Annals of Animal Science. Institut zootechniki, T. 26, pp. 219-228.

12. Hetmanska, B. and Tomasik, P., 1994. The metal-metal interactions in biological systems. Water, air and Soil Pollut, Vol. 74, №3-4, pp. 281-288.

13. Zhukorskyi, O., Semenov, S. and Semenov, Ye., 2018. Vplyv vazhkykh metaliv u ratsionakh na riven yikh nakopychennia v orhanakh i tkanynakh zabiinykh svynei, produktyvnist ta ekskretsiiu amiachnoho azotu [Influence of heavy metals in diets on the level of their acomulation in organs and tissues of slaughter pigs, productivity and extraction of ammoniac nitrogen]. Bulletin of Agricultural Science, №12 (789), pp. 40-45.

14. Roggeman, S., De Boeck, G., De Cock, H., Blust, R. and Bervoets, L., 2014. Accumulation and detoxification of metals and arsenic in tissues of cattle (Bos Taurus), and the risks for human consumption. Science of The Total Environment, № 466-467 
(1), pp. 175-184. DOl: https://doi.org/10.1016/j.scitotenv.2013.07/007.

15. Hashemi, S., 2018. Heavy metal concentrations in bovine tissues (muscle, liver and kidney) and their relationship with heavy metal contents in consumed feed. Ecotoxicokogy and Environmental Safety, №154 (15), pp. 263-267. DOI: https://doi.org/10.1016/j.ecoenv.2018.02.058.

16. Peng, L., Huang, Y., Zhang, J., Peng, Y., Lin, X., Wu, K. and Huo, X., 2015. Cadmium exposure and the risk of breast cancer in Chaoshan population of southeast China. Environmental Science Pollution Research, Vol. 22 (24), pp. 19870-19878. DOI: https://doi.org/10.1007/s11356-015-5212-1.

17. Savchenko, Y. I. and Savchuk, I. M., 1998. Transformatsiia nitrativ, radionuklidiv, solei vazhkykh metaliv u miaso buhaitsiv zalezhno vid optymizatsii vuhlevodnevoho zhyvlennia [Transformation of nitrates, radionuclides, salts of heavy metals into meat of bulls depending on optimization of hydrocarbon nutrition]. Bulletin of Agricultural Science, № 3, pp. 53-55.

18. Savchenko, Y. I., Savchuk, I. M., Savchenko, M. H. and Karpiuk, N. A. (Eds.), 2017. Radioekolohichna otsinka ratsioniv pry vyrobnytstvi yalovychyny [Radioecological evaluation of diets in beef production]. Monograph. Zhytomyr: Ruta.

19. Savchuk, I. M., Savchenko, Y. I., Savchenko, M. G. and etc. (Savchenko, Y. I., Savchuk, I. M. (Eds.)). 2014. Vykorystannia zernobobovykh na korm pry vyrobnytstvi moloka i miasa $v$ zoni Polissia [The use of legumes for feed in the production of milk and meat in the Polissya region]. Monograph. Zhytomyr: Ruta.

20. Ibatullina, I. I. and Zhukorskyi, O. M. (Eds.), 2017. Metodolohiia ta orhanizatsiia naukovykh doslidzhen u tvarynnytstvi [Methodology and organization of scientific research in animal husbandry]. Kyiv: Ahrarna Nauka.

21. Kandyba, V. M., Ibatullina, I. I. and Kostenko, V. I. (Eds.), 2012. Teoriia i praktyka normovanoi hodivli velykoi rohatoi khudoby [Theory and practice of standardized cattle feeding]. Zhytomyr: Ruta.

22. Ibatullina, I. I., Bashchenko, M. I., Zhukorskyi, O. M. and etc. (Ibatullina, I. I., Zhukorskyi, O. M. (Eds.)), 2016. Dovidnyk z povnotsinnoi hodivli silskohospodarskykh tvaryn [Handbook of complete feeding of farm animals]. Kyiv: Ahrarna Nauka.

Yashchuk Inna Vasylivna, Postgraduate Student, Polissya National University

Savchuk Ivan Mykolaiovych, Doctor of Agricultural Sciences, Senior Research Officer,

Institute of Agriculture of Polissia NAAS

The influence of protein nutrition of bulls on the accumulation of heavy metals in muscle tissue and liver

The paper studies the impact of bulls' protein nutrition under their keeping in the third zone of the radioactive contamination on the ecologic quality of production -the longest spinal muscle and the hepar. Two groups of young cattle were formed: the first group (the control one) - received a mixture of grains № 1 with blue lupine of local production as a basal ration; the second group (the experimental one ) received a mixture of grains №2 with "net product" field beans. The sample preparation of plant- and animal origin for estimating heavy metals in their composition was made by using a method of dry mineralization, the analysis was carried out on the atomic-absorption spectrometer "Kwant-2A". The transition coefficient (TC) of heavy metals in a chain "ration - production (muscle tissue and hepar)" was estimated by a formula: TC $=$ Chmap/Chmdr x 100, where Chmap - is the content of heavy metals in animal produce, $\mathrm{mg} / \mathrm{kg}$; Chmdr is the content of heavy metals in a daily ration, $\mathrm{mg}$. The use of the mixture of grains №2 (wheat + oats + field beans) for bull fattening in the zone of radioactive contamination instead of the same amount of the mixture of grains №1 (wheat + oats + lupin) had positive impact on the ecologic quality of beaf, reducing the amount of heavy metals in the longest spinal muscle. The accumulation of heavy metals in the longest spinal muscle and in a hepar of the experimental bulls was considerably lower than the permissible concentration rates. The substitution of lupin (30\%) in mass in the mixture of grains for a corresponding amount of field beans for young cattle under its fattening in the third zone of radioactive contamination is beneficial in reducing the accumulation and the transition of heavy metals into the muscle tissue of the animals: $P b-b y \quad 49,7 \%$ and $0,30 \%$ abs., $C d-25,0$ and $0,32, \mathrm{Cu}-8,3$ and 0,35 ; and $\mathrm{Zn}-$ by $1,1 \%$ and $0,12 \%$ abs. respectively.

Key words: bulls, the longest spinal muscle, hepar, blue lupin, field beans, concentration, heavy metals.

Дата надходження до редакції: 03.11.2021 р. 